\title{
TroyAcademy
}

International Journal of Social Sciences

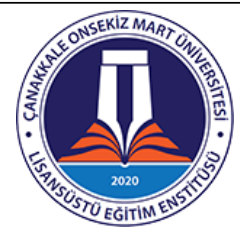

\section{Grup Sargınlığının Sosyal Kaytarma ve İş Tatmini Üzerindeki Etkisi ${ }^{1}$}

Araştırma Makalesi/Research Article

\section{Esra Burcu KAYA* Yener PAZARCIK**}

\section{ÖZET}

Bu çalışmada, grup sargınlığının sosyal kaytarma ve iş tatmini üzerindeki etkisinin incelenmesi amaçlanmıştır. $\mathrm{Bu}$ doğrultuda Çanakkale ili ve ilçelerindeki lojistik sektöründe faaliyet gösteren bir firma araştırmanın örneklemini oluşturmaktadır. Araştırmada anket tekniğinden yararlanılmıştır. Elde edilen veriler, açıklayıcı ve doğrulayıcı faktör analizleri ile korelasyon ve regresyon analizleriyle değerlendirilmiştir. Bulgular, grup sargınlığının alt boyutları olan grubun sosyal bütünleşmesi- grubun sosyal çekiciliği ve grubun görev çekiciliği ile sosyal kaytarma davranışı ve iş tatmini arasında istatistiksel olarak anlamlı ilişkiler olduğunu göstermektedir. Buna ek olarak araştırma modelinde yer alan grup sargınlı̆̆1 (grubun sosyal bütünleşmesi- grubun sosyal çekiciliği ve grubun görev çekiciliği) bağımsız değişkeninin, sosyal kaytarma ve iş tatmini bağımlı değişkenlerini etkilediği ortaya konulmuştur.

Anahtar Kelimeler: Grup Sargınlı̆̆l, Sosyal Kaytarma, İ̧ Tatmini

\section{The Effect of Group Cohesiveness on Social Loafing and Job Satisfaction}

\begin{abstract}
This study aims to explore the effect of group cohesiveness on social loafing and job satisfaction. In this direction, research sample consists of a company in business with logistic sector located in Çanakkale province and its districts. In this study questionnaire technique is used. Obtained data is evaluated with explanatory and confirmatory analysis and correlation and regression analysis methods. The findings show us that there are statistically meaningful relationships between social integration, social attraction and task attraction of the group which are sub-types of the group cohesiveness; and behavior of social loafing and job satisfaction. In addition, it is presented that independent variable of group cohesiveness (social integration, social attraction and task attraction of the group) in this research model affects dependent variables: social loafing and job satisfaction.
\end{abstract}

Keywords: Group Cohesiveness, Social Loafing, Job Satisfaction

\footnotetext{
${ }^{1} \mathrm{Bu}$ çalışma aynı adlı yüksek lisans tezinden hazırlanmıştır.

* Çanakkale Onsekiz Mart Üniversitesi, Uluslararası Ticaret ve Lojistik Anabilim Dalı, burcukaya017@gmail.com, ORCID ID: https://orcid.org/0000-0002-0300-8636

** Doç. Dr., Çanakkale Onsekiz Mart Üniversitesi, Uluslararası Ticaret ve Lojistik Anabilim Dalı, ypazarcik@comu.edu.tr, ORCID ID: https://orcid.org/0000-0002-7651-9349
} 


\section{GíRiş}

Grup sargınlığı, örgüt içindeki grupların devamlılığının sağlanmasında önemli bir rol oynamasından dolayı araştırmacıların üzerinde durduğu bir kavram olmuştur (Kowlowski ve Ilgen, 2006: 87). Grup sargınlığı kavramı, grup halinde çalışan bireylerin kendilerini o grubun bir parçası gibi hissetmeleri ve grup içerisinde varlıklarını sürdürebilmelerinde gerekli olan güçlerin birleştirilmesi şeklinde ifade edilmektedir. Grup içindeki üyeler arasındaki bağın güçlendirilmesi, grup sargınlığındaki düzeyin de arttırılmasına etki etmektedir. Buna ek olarak grup içindeki sargınlık düzeyinin arttırılması için sosyal ilişkilere verilen fazla önemin bireylerdeki iş performansında etki yaratarak verimlilik kaybına yol açabileceği görülmektedir (Barl1, 2007: 49).

Grup halinde çalışan bireylerin, bilinçli veya bilinçsiz bir şekilde oluşan sosyal farkındalıklarındaki azalma, bireylerin tek başına olduklarına oranla daha az çaba sarf etmelerine yol açmakta ve sonuç olarak verimliliğin azalması sosyal kaytarma davranışını ortaya çıkarmaktadır (Kanten, 2014: 13). Grup halinde çalışmanın sonucu olan sosyal kaytarma davranışı, örgüt içinde kabul edilemeyen bir davranıştır. Çünkü sosyal kaytarma davranışıyla bireylerin gösterdikleri bireysel performans net bir biçimde ölçülememekte ve grup halinde yapılan işlerde bireysel yapılan işlere nazaran daha az çaba sarf edildiği görülmektedir (Kılıçarslan, 2018: 8). Bununla birlikte sosyal kaytarma davranışı, grup içinde yer alan diğer üyelerde hayal kırıklığı yaşanmasına, üretkenliğin azalmasına, bireysel yeteneklerin engellenmesine, tatminsizliğe ve tükenmişliğe yol açabilmektedir (Açar, 2018:17).

Grup halinde çalışılan örgütlerde, örgüt amaçlarına başarılı bir şekilde ulaşılabilmesi bireylerin diğer üyelerle arasındaki uyum ve bireysel güdüleyicilere bağlıdır. Bireyler günlerinin önemli bir parçasını iş arkadaşlarıyla geçirmektedir bundan dolayı iş arkadaşlarıyla geçirilen zamandan alınan zevk bireysel iş tatminini de doğrudan etkilemektedir (Emre, 2016: 11).

Bireylerin ihtiyaçlarının karşılanması ve yoğun iş tempolarına uyum sağlayabilmeleri örgüt içi bağlılık, iletişim, verimlilik, moral ve iş tatmini vb. birçok etmene bağlıdır. Buna bağlı olarak çalışma ortamındaki verimlilik ve tatminin arttırılması için gerekli şartların oluşmasında önemli rol oynayan grup sargınlığı, örgüt içerisinde düzeylerinin arttırılması halinde olumsuz davranışların da engellenmesine yardımcı olacaktır. Bu bilgiler araştırmanın çıkış noktasını oluşturmaktadır. Araştırmanın amacı lojistik sektöründe grup halinde çalışan bireylerin grup sargınlıklarının sosyal kaytarma ve iş tatmini üzerindeki etkisinin incelenmesi olarak belirlenmiştir. 


\section{LITERATÜR TARAMASI}

\subsection{Grup Sargınlığı}

Sargınlık kavramı latincede "cohaesus" kelimesinden gelmekte olup sıkı bağ oluşturan ve birbirine tutunan anlamına gelmektedir. Sosyal psikoloji alanında sargınlık kavramı, grupta bulunan üyelerin birbirine kenetlenmesi ve üyeler arasındaki bağlılığı belirtmek için kullanılmaktadır. Sosyal psikoloji alanında grup kavramı iki veya daha fazla kişiden oluşan sosyal bir ünite olarak ifade edildiğinden dolayı grubun var olması halinde sargınlığında belirli bir düzeyde bulunması söz konusu olabilmektedir (Kocaekşi, 2010:13).

Sargınlık kavramı, grupların oluşmasında ve devamlılığın sağlanmasında önemli bir değişken olarak kabul edilmektedir. Sosyal, örgüt, klinik ve spor psikolojisi alanında birçok araştırmacı tarafından ilgilenilen bir konu olmuştur. Buna bağlı olarak sargınlık kavramının çok sayıda tanımı bulunmaktadır. Bunun sebebi olarak çok fazla alanda çalışılmış bir kavram olduğu görülmektedir (Tümbaşer, 2020: 24).

Grup sargınlığı kavramı, 1940 ve 1950 yıllarında grup süreçleri bağlamında yapılan sosyal, psikolojik ve deneysel araştırmaların sonucu olarak bulunmuştur (Hogg, 1993: 85-86). Sargınlık kavramı ilk kez Moreno ve Jenning (1991) tarafından “grup içerisinde üye olarak kalınmasını sağlayan bir güç” olarak ifade edilmiştir (Mudrack, 1989:41). Goodman vd. (1987) sargınlık kavramını " gruptaki üyelerin görevlerine bağlılığı", Piper vd. (1983) kavramı benzer biçimde "gruba bağlanma", Festinger vd. (1950) "belirli amaçları başarabilmek için grubun bir arada kalma eğilimini kapsayan güçler toplamı" şeklinde tanımlamışlardır (Kocaekşi, 2010:13). Sargınlık kavramının en kapsamlı tanım olarak kuramcılar tarafından da kabul gördüğü tanım ise " gruptaki üyelerin duygusal, araçsal gereksinimlerinin karşılanma düzeylerinden etkilenen, üyelerin birbirleriyle kenetlenmelerini ve bağlanmalarını amaçlayan dinamik süreçler” şeklinde ifade edilmektedir (Cota vd., 1995: 572). Bu tanım ile birlikte sargınlık kavramı daha kapsamlı bir şekilde incelenerek görev sargınlığı ve sosyal sargınlık kavramları üzerinden de açıklanabilir hale gelmiştir.

Carron vd. (1992), gruplardaki sargınlık düzeyini ölçmek ve açıklamak amacıyla bir model geliştirmişlerdir. Yapılan bu çalışmada sargınlık kavramını birey ve grup olarak incelemenin yanı sıra görev ve çevresel bağlantılarının da eklendiği kapsamlı bir araştırma gerçekleştirmişlerdir. Carron ve arkadaşlarına (1998) göre, birey ve grup etkilerine bakıldığında bu boyutlara grup bütünleşmesi ve grup çekiciliği kavramları eklendiğini ve bu iki alt boyutun da görev ve sosyal açıdan desteklendiğini belirtmişlerdir. Bu araştırma doğrultusunda grup sargınlığı, grubun sosyal bütünleşmesi; gruptaki sosyal ilişkilerin geliştirilebilmesi ve sürdürülebilmesini, grubun görevde bütünleşmesi; grup 
amaçlarının gerçekleştirilebilmesi için görevde bütünlük kurulabilmesini, grubun sosyal çekiciliği; gruba ilişkin sosyal aktivitelere katılma isteğini, grubun görev çekiciliği; gruba ilişkin amaçlara ulaşılması için amaca duyulan çekiciliği ifade eden grup dört boyutlu bir yapı haline gelmiştir (Carron vd., 1985: 248). Bu çalışma ile sargınlık kavramının çok boyutlu, etkin, amaca yönelik ve etkileşim içermesi unsurlarını anlamlı bir çerçevede açıklanmasını da desteklemiştir. Buna göre sargınlık çok boyutudur; bir grubun bütün olması ve birbirlerine bağlı olması gruplara göre değişiklik gösterebilmektedir. Grup üyelerinin birbirlerinden hoşlanmamaları ve iletişim olarak güçlü olmamalarına rağmen görev sargınlığı gösterebildikleri gibi başka bir grubun üyeleri iletişim anlamında güçlü bağlara sahip olmasına rağmen görev sargınlığı sergilemede yetersiz oldukları görülebilmektedir. Ancak her iki takımın da belirli düzeyde sargınlık gösterdikleri görülmektedir. Sargınlık etkin bir kavramdır; üyeler arasındaki sargınlık kavramı sabit değil aksine dinamik bir kavram olduğu belirtilmiştir. Grup içerisindeki yüksek sargınlık düzeyi gruba dahil olan bir bireyin dahil olması veya yöneticinin değişmesi gibi etkenlerden etkilenen bir kavramdır. Sargınlık amaca yönelik bir kavramdır; bir grubun kurulmasında belirli bir amaç vardır ve bu doğrultuda maddi çıkarlarında sağlanabildiği görülebilmektedir. Sokak çocuklarına yardım etmek amacıyla kurulan bir grubun sosyal bir amacının bulunmasının yanı sıra üyelerin katılımıyla da çevrelerini genişletmeleri bireysel anlamda iş imkânlarını genişletmesi anlamında da örnek olarak verilebilmektedir. Sargınlık kavramı etkileşim gerektiren bir kavramdır; görev sargınlığı bilinciyle hareket eden bir grubun amaçlara ulaşmada grup iletişiminin kuvvetli olması gerekmektedir (Kocaekşi, 2010: 15-16).

\subsection{Sosyal Kaytarma}

Önemli olarak görülen birçok görev grup olarak çalış1lması durumunda başarıya ulaşabilmektedir. Grup görevleri her bir üyenin bireysel girdilerindeki birikimin ortaklaşa görevlerde oldukça önemli olduğu görülmektedir. Spor takımları, orkestralar, örgütler vb. gibi her bir üyenin kişisel emeklerinin tek bir ürün elde edebilmek için birleştirmesi örnek olarak gösterilebilir. Ortak olarak yapılan görevlerin yaygın olması ve göz ardı edilememesi dikkate alındığında, hangi etmenlerin bireyleri bu alanda motivesini arttırdığını veya azalttığını belirlemenin önemine vurgu yapmaktadır (Karau ve Williams, 1993: 681).

Gruplarda birlikte çalışmanın bireylerdeki motivasyonun en üst seviyeye çıkması ve çalışma azmindeki artış yaşanması gibi olumlu etkileri olduğu gözlemlenmektedir. Ancak bir takım durumlar araştırmalarda, bireylerin grup halinde çalıştıklarında bireysel olarak çalışmalarına kıyasla daha az çaba gösterdiklerini ortaya koymuştur (Karau ve Williams, 1997: 156). Gruplardaki sosyal farkındalıklarında oluşan bilinçli veya bilinçsiz azalmanın yaşanması, bireylerin tek başına daha az gayret göstermelerine yol açtı̆̆ı gözlemlenmiştir (Ilgın, 2013: 240). Örgütlerde yaşanan bu verimlilik 
kayıplarının sosyal kaytarma kavramıyla açıklandı̆̆ı görülmektedir (George, 1992:191). Sosyal kaytarma davranışı insanların tek başına çalışmalarının tersine grup olarak çalışmaları halinde meydana gelmesi beklenen kimlik belirsizliğine dayanmaktadır (Liden vd., 2004: 285).

Sosyal kaytarma, bireylerin ortak çalışmalarındaki çaba ve motivasyonlarının, bireysel olarak çalışmalarına oranla azalması durumudur. Sosyal kaytarma kavramı ilk kez kullanan Latene vd. (1979:822), verimliliğin önemli düzeyde düşmesine neden olan ve bireysel çalışmalarda yaşanmayan daha çok grup halinde çalışılması durumunda ortaya çıkan bu kavramı, yaratmış olduğu bir takım sıkıntılardan yola çıkarak "toplumsal bir hastalık" olarak ifade etmişlerdir.

Sosyal kaytarma davranışının belirlenmesinde yapılan ilk çalışma 1880'li yıllarda bir halat çekme görevinin grup halinde yapılması durumunda olası etkileri inceleyen Ringelmann tarafindan gerçekleştirilmiştir (William ve Karau, 1991: 570). Ringelmann bir grup erkeklerden bireysel ve grup olarak halatları çekmelerini istemiştir. Deneyin sonucunda, bireysel olarak çekilen halatların kuvvetlerinin grup halinde çekilen halatların kuvvetine eşit olmadığı görülmektedir. Buna ek olarak Ringelmann deneyde gruplardaki birey sayılarında yaşanan artışın toplam performansta azalmasın neden olduğunu belirtmiştir. Ringelmann'ın belirlediği grup büyüklüğü ile sarf edilen çabanın arasındaki zıt yönlü ilişkiyi "Ringelmann Etkisi” olarak isimlendirilmektedir (Piezon ve Ferree, 2008:2). Latane vd. (1979: 822) gerçekleştirdikleri deneylerde, bireylerin fiziksel güç gerektiren (bağırma, halat çekme, alkışlama) görevlerde grup halinde çalıştıklarında gösterdikleri çabaların yalnız başına sarf ettiği çabalardan daha az olduğu ortaya çıkmıştır. Bu deney ile birlikte bireylerin gruplarda sarf ettikleri çabaların düşüklüğünün azalan bireysel çabayla bağlantılı olabileceği belirtilmiştir (Karau ve Williams,1993: 682). Latane vd. (1979:822) bu deneyler sonucunda gruplardaki bireysel performansın düşmesine "Sosyal Kaytarma” tanımlamasını kullanmışlardır.

\section{3. İș Tatmini}

İş tatmini kavramının günümüzde daha da önemli hale gelmesinin nedeni, örgüt içindeki insan kaynaklı problemlerin giderek artması ve bu problemlerin giderilmesi gösterilebilmektedir (Şahal, 2005: 49). Bununla birlikte örgüt içerisindeki bireylerin iş tatminlerini ölçmeyi amaçlayan araştırmalar da bulunmaktadır. Birçok araştırmaya konu olan iş tatmini kavramı bireylerin işlerine göstermiş oldukları pozitif duyguların tümüdür (Erdoğan,1996:248). Bireyin iş tatminin yüksek olması, bireyin işini sevdiğini ve işinin pozitif değerlere sahip olduğu bunun yanında bireyin örgüte yönelik olumlu bakış açısına da sahip olduğu söylenebilir. Locke (1976) ve Oshagbemi (1999) iş tatminini bireyin işine karşı duyduğu olumlu his ve duygu şeklinde tanımlarken Vroom (1964) bu tanıma uyum kavramını da dahil etmiştir. Bireyin işine olan olumlu tavrı işinden tatmin olduğunu, aksi durum olan olumsuz bir tutumun ise tatmin seviyesinin düşük olduğunu veya işten hiç tatmin 
olunmadığını göstermektedir. Bu bağlamda işin tüm boyutları bireyin işe karşı tatmin olunmasında etkili olmaktadır. İşinden belli derecede tatmin sağlayan bireyin işlerine karşı sevgi besledikleri ve saygı duyduklarından bahsedilebilir (Özpehlivan, 2018:45). Bazı araştırmacılar iş tatmini ve tatminsizlik kavramlarını bireyin işinden beklentisi, çevresinin kendisine kattığı imkan ve fırsatların düzeyi ile bağlantılı olacağını ileri sürmektedirler. İş tatmini düzeyi, beklenti ve tecrübe edilen arasındaki fark şeklinde ifade edilebilir. Örneğin istenilen tek yönlü ve basitlik içeriyorsa birey işini basmakalıp ve sıkıcı bularak beklentilerini azaltacaktır (Kök, 2006: 293).

İş tatminini etkileyen birçok etken saymak mümkündür. Fakat iş tatminini genel bağlamda iki ana unsura bağlamak daha sağlıklıdır. Unsurlardan ilki kişinin bireysel durumu; bireyin yapısı, istekleri, duygu ve düşünceleri ile içinde bulunduğu gereksinimler ve bunların şiddet düzeyleriyle ilgilidir. İkinci unsur ise işe yönelik koşullardır. İşe yönelik psikolojik ve fiziksel şartlar ile bu şartların bireyin beklentilerine cevap verme düzeyleri ile ilgilidir. Bu şartların bireylerin beklentilerini karşılama

düzeylerindeki yüksekliği işten alınan tatmin seviyesinin de yüksek olmasını sağlayacaktır (Erişen vd., 2019: 6910).

Farmer ve Richman'a (1975) göre bireysel gereksinimler, umutlar, kendini tanıma, kendine sayg1 duyma, başarılı olma düzeyinin iş tatmini ile ilişkili olduğunu belirtmektedir. Benlik duygusu gelişmiş, kendini gerçekleştirme ve kendine güven düzeyleri yüksek olan bireylerin işlerinden daha fazla tatmin oldukları gözlemlenmiştir. İşe yönelik koşullara bakıldığında ise işin niteliği, işte yükselme olanakları, ücret, denetim, kabul görme, ekip arkadaşları ve yönetimin etkili olduğu görülmektedir. Bu bağlamda iş tatmini bir bütün olarak bireyin işi ve çevresi, yönetim şekilleri, yönetim politikaları, işyeri arkadaşlıkları, işten elde edilen ekonomik getiriler vb. algıları ile ilgilidir. Ve temelde ücret politikası ve ücret dağıtımındaki adalet, iş ve işin ilginçlik düzeyleri, işin öğrenme imkanı sağlama düzeyleri, işin terfi olanakları, yöneticinin bireye karşı tutumu, örgütteki arkadaşlık ilişkileri gibi etmenler tarafından etkilenmektedir (Kök,2006: 294).

\section{YÖNTEM}

\subsection{Araştırmanın Amacı ve Yöntemi}

Grup sargınlığının sosyal kaytarma ve iş tatmini üzerindeki etkisini incelemek araştırmanın amacını oluşturmaktadır. Araştırmada veri toplama yöntemi olarak anket tekniğinden yararlanılmıştır. Anket formunda grup sargınlığı, sosyal kaytarma ve iş tatmini düzeylerinin ölçülmesi için üç farklı ölçek kullanılmıştır. Ölçeklerin içinde bulunan ifadelerin yanıtları için beş aralıklı Likert tipi metrik ifadeye yer verilmiştir. 


\subsection{Araştırma Modeli ve Hipotezler}

Araştırma modelinde tanımlayıcı model kullanılmıştır. Araştırma modelinde bir bağımsız (grup sargınlığı) ve iki bağımlı değişken (sosyal kaytarma ve iş tatmini) yer almaktadır. Araştırmada grup sargınlığ dört alt boyutlu, sosyal kaytarma ve iş tatmini tek boyutlu olarak ele alınmıştır. Araştırma modeli Şekil 2.1'de ve araştırma hipotezleri aşağıda yer almaktadır.

Şekil 2.1. Araştırma Modeli

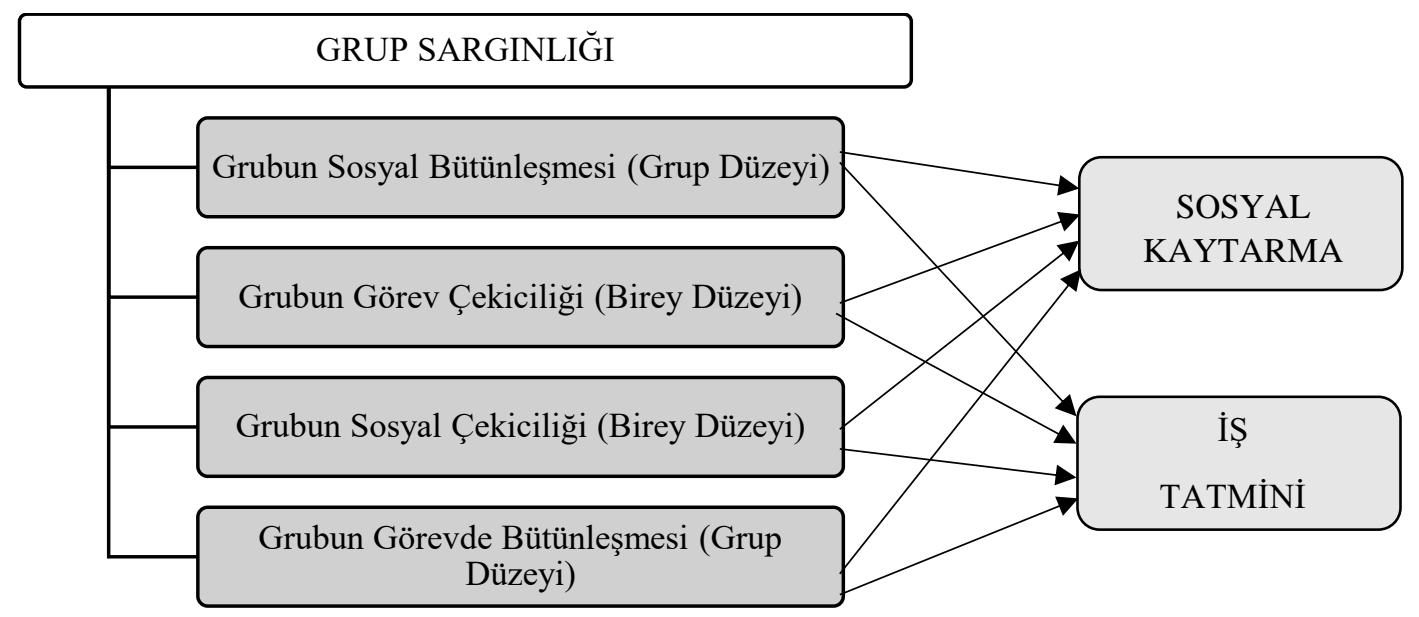

H1: Grup sargınlığı çalışanların sosyal kaytarma davranışlarını etkilemektedir.

H1a: Grup sargınlığının grubun sosyal bütünleşmesi boyutu çalışanların sosyal kaytarma davranışlarını etkilemektedir.

H1b: Grup sargınlığının grubun görev çekiciliği boyutu çalışanların sosyal kaytarma davranışlarını etkilemektedir.

H1c: Grup sargınlığının grubun sosyal çekiciliği boyutu çalışanların sosyal kaytarma davranışlarını etkilemektedir.

H1d: Grup sargınlığının grubun görevde bütünleşmesi boyutu çalışanların sosyal kaytarma davranışlarını etkilemektedir.

H2: Grup sargınlığı çalışanların iş tatmin düzeylerini etkilemektedir.

H2a: Grup sargınlığının grubun sosyal bütünleşmesi boyutu çalışanların iş tatmin düzeylerini etkilemektedir.

H2b: Grup sargınlığının grubun görev çekiciliği bütünleşmesi boyutu çalışanların iş tatmin düzeylerini etkilemektedir. 
H2c: Grup sargınlığının grubun sosyal çekiciliği boyutu çalışanların iş tatmin düzeylerini etkilemektedir.

H2d: Grup sargınlığının grubun görevde bütünleşmesi boyutu çalışanların iş tatmin düzeylerini etkilemektedir.

\subsection{Araştırmanın Örneklemi}

Araştırma Çanakkale ili ve ilçelerindeki lojistik sektöründe faaliyet gösteren bir firmada kolayda örnekleme yöntemi ile gerçekleştirilmiştir. Firmadan alınan araştırma izni doğrultusunda araştırmada mavi yaka ve beyaz yaka çalışanlar örnekleme dahil edilmiştir. Firmaya teslim edilmiş olan toplam 250 anket formundan 222 adet (\%88.8) formun 198'i (\%79,2) değerlendirilmeye alınmıştır.

\subsection{Araştırmanın Ölçekleri}

Anket formlarının oluşturulmasında ulusal ve uluslararası nitelikteki çalışmalardan faydalanılmıştır. Anket formunda, işgörenlerin grup sargınlığı, sosyal kaytarma davranışlarını ve iş tatmin düzeylerini ölçmek için üç farklı ölçekten yararlanılmıştır. Ölçeklerde bulunan ifadelerin cevapları için eşit oldukları varsayılan beş aralıklı Likert tipi metrik ifade ("Kesinlikle katılmıyorum”, "Katılmıyorum”, "Ne katılıyorum ne katılmıyorum”, “Katılıyorum” ve “ Kesinlikle katılıyorum”) kullanılmıştır. Buna ek olarak anket formunda işgörenlerin demografik bilgilerini belirleyebilmek için 8 demografik soru yer almaktadir.

Grup Sargınlığı Ölçeği; Carron vd. (1985) geliştirdiği, Öcel ve Aydın (2006) tarafından Türkçeye uyarlanan Grup Sargınlığı ölçeği kullanılmıştır. Grup sargınlığı ölçeğinde; grubun sosyal bütünleşmesi, grubun görev çekiciliği, grubun sosyal çekiciliği ve grubun görevde bütünleşmesi boyutlarına ilişkin 18 ifade yer almaktadır. Sosyal Kaytarma Ölçeği; Liden vd. (2004) geliştirdiği, Ilgın (2010) tarafından Türkçeye uyarlanan Sosyal Kaytarma Ölçeği kullanılmıştır. Sosyal kaytarma ölçeğinde 13 ifade yer almaktadır. İş Tatmini Ölçeği; Hackman ve Oldman'ın (1975) geliştirdiği, Basım ve Şeşen'in (2009b) tarafından Türkçeye uyarlanan İş Tatmini Ölçeği kullanılmıştır. İş tatmini ölçeğinde 5 ifade yer almaktadır.

\section{BULGULAR}

\subsection{Demografik Bulgular}

Araştırmaya katılan firma çalışanlarının \%18'i kadın, \%81'i erkektir. Katılımcıların \%74'ü 34-49 yaş aralığındaki çalışanlarda oluşmaktadır. Çalışanların önemli bir kısmının Lise mezunu olduğu görülmektedir. Çalışanların unvan dağılımlarına bakıldığında, \% 79'unun mavi yaka çalışanlarından oluştuğu görülmektedir. Çalışanların \% 65'inin evli olduğu bunun yanında gelir düzeyi \%40 ile 2501$3500 \mathrm{Tl}$ olduğu görülmektedir. Çalışanların büyük bir kısmının 1-5 yıl arası çalışma süresine sahip 
bireyler olduğu görülmektedir. Son olarak katılımcıların çalışma grubu sayılarına bakıldığında \%63,6 oranı ile küçük gruplarda yani 1-10 kişilik gruplardan oluştuğu görülmektedir.

Tablo 3.1. Demografik Veriler

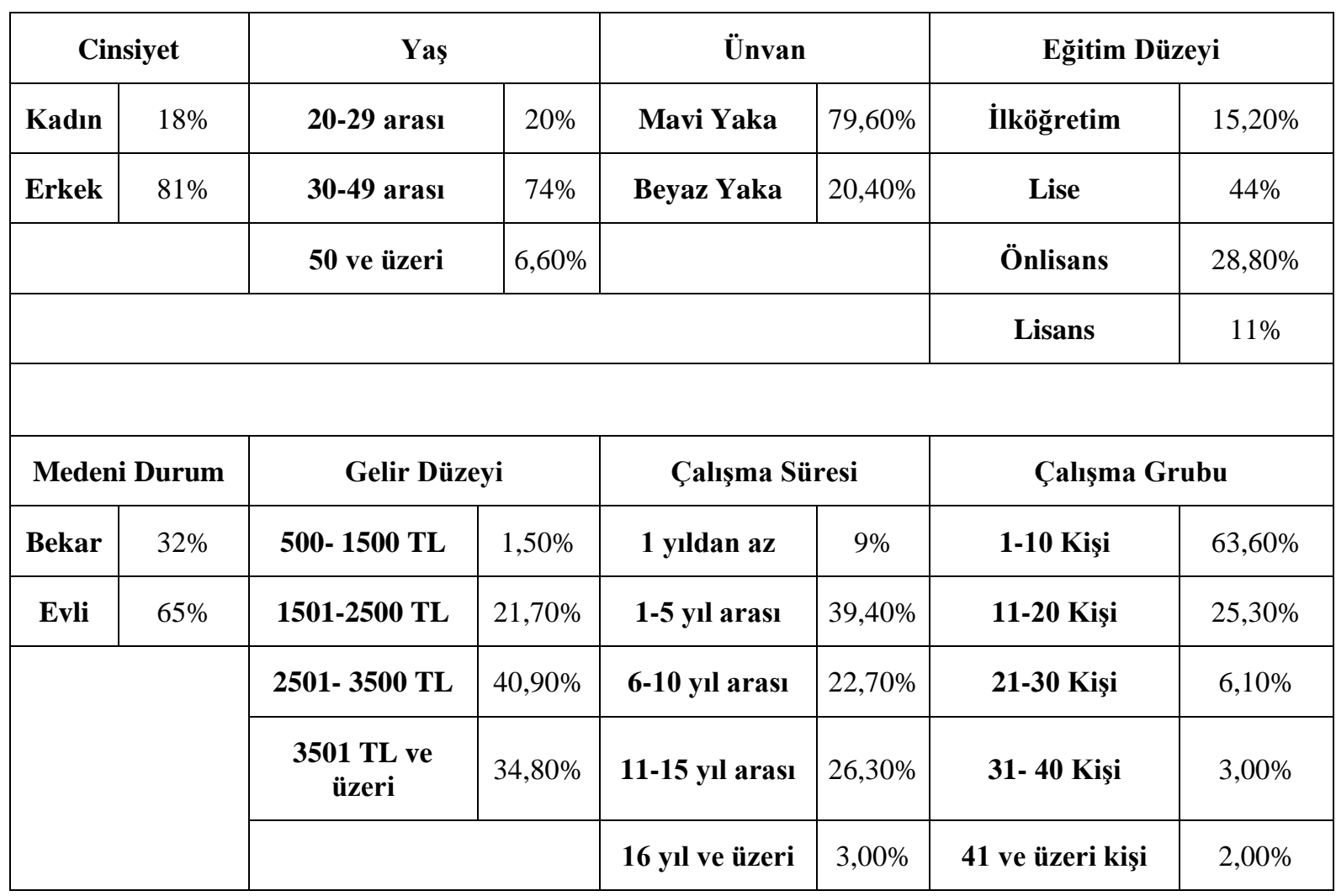

\subsection{Faktör Analizi Bulguları}

Araştırmada yer alan grup sargınlığı ölçeği için grubun sosyal bütünleşmesi, grubun görev çekiciliği, grubun sosyal çekiciliği ve grubun görevde bütünleşmesi boyutlarına ilişkin toplam 18, sosyal kaytarma ölçeği için toplam 13 ve iş tatmini ölçeği için toplamda 5 ifadenin yapı geçerliliğinin test edilmesi amacıyla açıklayıcı faktör analizi uygulanmıştır. Araştırma verilerinin faktör analizi için uygun olup olmadığının belirlenmesinde kullanılan Kaiser-Meyer-Olkin (KMO) testi ile örneklemin faktör analizi için yeterli olduğunu grup sargınlığı ölçeği (KMO değeri. 646), sosyal kaytarma ölçeği (KMO değeri. 875), iş tatmini ölçeğinde (KMO değeri .816) görülmektedir. Açıklayıcı faktör analizi sonucunda grup sargınlığı ölçeğindeki 8 madde ve sosyal kaytarma ölçeğindeki 3 maddenin faktör yüklerinin 0.50'nin altında kalmasından dolayı analiz dışında tutulmuş olup kalan maddelerin de teoriye uygun bir yapıyı ölçtüğü tespit edilmiştir. Grup sargınlığg ölçeğinde kalan maddelerin faktör yüklerinin. 51 ile. 73 arasında olduğu, sosyal kaytarma ölçeğinde kalan maddelerin faktör yüklerinin .51 ile .87 arasında olduğu ve iş tatmini ölçeğindeki maddelerin .61 ile .84 arasında olduğu belirlenmiştir. Yapılan güvenilirlik analizi sonucunda grup sargınlığı ölçeğinin Cronbach alfa 
güvenilirlik katsayısının .64, sosyal kaytarma ölçeğinin .87 ve iş tatmini ölçeğinin .81 olduğu bulunmuştur.

Açıklayıcı faktör analizlerinin sonuçları Lisrel 9.1 programıyla desteklenerek doğrulayıcı faktör analizinin yapılması sonucunda üç ölçeğin uyum iyiliği değerleri hesaplanarak Tablo 3.2'de araştırmanın ölçeklerine dair doğrulayıcı faktör analizi sonuçları gösterilmektedir.

Tablo 3.2. Doğrulayıcı Faktör Analizi Sonucunda Ölçeklerin Uyum İyiliğine İlişkin Değerlerin Dağılımı

\begin{tabular}{|c|l|l|l|l|l|l|l|l|c|}
\hline Değişkenler & \multicolumn{1}{|c|}{$\mathbf{x}^{\mathbf{2}}$} & $\mathbf{d . f .}$ & $\mathbf{x} / \mathbf{d f}$ & $\mathbf{G F I}$ & AGFI & CFI & NFI & NNFI & RMSEA \\
\hline Grup Sargınlı̆̆ı & 17,06 & 15 & 1,13 & 0,98 & 0,95 & 0,99 & 0,94 & 0,98 & 0,026 \\
\hline $\begin{array}{c}\text { Sosyal } \\
\text { Kaytarma }\end{array}$ & 48,35 & 24 & 2,01 & 0,95 & 0,90 & 0,98 & 0,97 & 0,97 & 0,072 \\
\hline İş Tatmini & 4,874 & 4 & 1,21 & 0,99 & 0,96 & 0,99 & 0,99 & 0,99 & 0,033 \\
\hline
\end{tabular}

Tablo 3.2'de yer alan $\mathrm{x}^{2} / \mathrm{df}$, GFI, AGFI, CFI, NFI, NNFI, RMSEA bu değerlerin grup sargınlı̆̆ı, sosyal kaytarma ve iş tatmini ölçekleri için kabul edilebilir değerler arasında bulunduğu görülmektedir.

\subsection{Korelasyon Analizi Bulguları}

Araştırmadaki değişkenlerin arasındaki ilişkileri ve birbirleriyle olan ilişkilerin yön ve kuvvet düzeylerinin tespit edilmesi amacıyla korelasyon analizi yapılmıştır. Tablo 3.3'te hesaplanan değerler gösterilmektedir.

Tablo 3.3. Grup Sargınlığı ve Alt Boyutları, Sosyal Kaytarma ve İş Tatminine Yönelik Korelasyon Analizi Sonuçları

\begin{tabular}{|c|c|c|c|c|c|c|}
\hline & & $\begin{array}{c}\text { Grup } \\
\text { Sargınlığı }\end{array}$ & $\begin{array}{c}\text { Grubun Sos. } \\
\text { Büt- Sosyal } \\
\text { Çek. }\end{array}$ & $\begin{array}{c}\text { Grubun } \\
\text { Görev Çek. }\end{array}$ & $\begin{array}{c}\text { Sosyal } \\
\text { Kaytarma }\end{array}$ & İş Tatmini \\
\hline \multirow{2}{*}{$\begin{array}{l}\text { Grup } \\
\text { Sargınlığı }\end{array}$} & $\begin{array}{c}\text { Pearson } \\
\text { Correlation }\end{array}$ & 1 &, $857^{* *}$ &, $690^{* *}$ &,$- 558^{* *}$ &, $359^{* *}$ \\
\hline & Sig.(2-tailed) & &, 000 &, 000 & ,000 & ,000 \\
\hline \multirow{2}{*}{$\begin{array}{l}\text { Grubun Sosyal } \\
\text { Bütünleşmesi- } \\
\text { Grubun Sosyal } \\
\text { Çekiciliği }\end{array}$} & $\begin{array}{c}\text { Pearson } \\
\text { Correlation }\end{array}$ &, $857^{* *}$ & 1 &, $217^{* *}$ &,$- 465^{* *}$ &, $349^{* *}$ \\
\hline & Sig.(2-tailed) & ,000 & &, 002 & ,000 & ,000 \\
\hline \multirow{2}{*}{$\begin{array}{l}\text { Grubun Görev } \\
\text { Çekiciliği }\end{array}$} & $\begin{array}{c}\text { Pearson } \\
\text { Correlation }\end{array}$ &, $690^{* *}$ &, $217^{* *}$ & 1 &,$- 403^{* *}$ &, $190^{* *}$ \\
\hline & Sig.(2-tailed) & ,000 &, 002 & & ,000 & ,007 \\
\hline Sosyal Kaytarma & $\begin{array}{c}\text { Pearson } \\
\text { Correlation }\end{array}$ &,$- 558^{* *}$ &,$- 465^{* *}$ &,$- 403^{* *}$ & 1 &,$- 176^{*}$ \\
\hline
\end{tabular}




\begin{tabular}{|l|c|c|c|c|c|c|}
\hline & Sig.(2-tailed) &, 000 &, 000 &, 000 & &, 013 \\
\hline \multirow{2}{*}{ İs Tatmini } & $\begin{array}{c}\text { Pearson } \\
\text { Correlation }\end{array}$ &, $359^{* *}$ &, $349^{* *}$ &, $190^{* *}$ &,$- 176^{*}$ & 1 \\
\cline { 2 - 7 } & Sig.(2-tailed) &, 000 &, 000 &, 007 &, 013 & \\
\hline \multirow{2}{*}{$*$ Kolerasyon 0,01 düzeyinde/ * $\mathbf{0 , 0 5}$ düzeyinde anlamlıdır. }
\end{tabular}

Tablo 3.3.'de grup sargınlığı (grubun sosyal bütünleşmesi-grubun sosyal çekiciliği, grubun görev çekiciliği) sosyal kaytarma ve iş tatmini boyutları arasındaki korelasyon analizi sonuçları yer almaktadır.

Araştırmada grup sargınlığı ve alt boyutları ile sosyal kaytarma boyutları arasında anlamlı ilişkiler görülmektedir. Buna göre; çalışanların grup sargınlığı ile sosyal kaytarma arasında olumsuz yönde $(\mathrm{r}=-, 558 ; \mathrm{p}<0,01)$ anlamlı bir ilişiki, grup sargınlığının alt boyutu olan grubun sosyal bütünleşmesigrubun sosyal çekiciliği ile sosyal kaytarma arasında olumsuz yönde $(r=-, 465 ; p<0,01)$ anlamlı bir ilişki, grup sargınlığının alt boyutu olan grubun görev çekiciliği ile sosyal kaytarma arasında olumsuz yönde $(r=-, 403 ; p<0,01)$ anlamlı bir ilişki tespit edilmiştir.

Grup sargınlığı ve alt boyutları ile iş tatmini boyutları arasında anlamlı ilişkiler görülmektedir. Çalışanların grup sargınlığı ile iş tatmini arasında olumlu yönde $(r=, 359 ; p<0,01)$ anlamlı bir ilişki, grup sargınlığının alt boyutu olan grubun sosyal bütünleşmesi- grubun sosyal çekiciliği ile iş tatmini arasında olumlu yönde $(r=, 349 ; p<0,01)$ anlamlı bir ilişki, grup sargınlığının alt boyutu olan grubun görev çekiciliği ile iş tatmini arasında olumlu yönde $(\mathrm{r}=, 190 ; \mathrm{p}<0,01)$ anlamlı bir ilişki görülmektedir.

\subsection{Regresyon Analizi Bulguları}

Korelasyon analizi ile araştırma değişkenleri arasındaki ilişkinin varlığı test edilmiş ancak değişkenlerin birbirlerini ne oranda etkilediği gözlemlenememiştir. Sonuç olarak korelasyon analizi bulgularından destek alınarak araştırmada yer alan bağımsız değişkenin (grup sargınlığı) bağımlı değişkenleri olan sosyal kaytarma ve iş tatminini ne düzeyde etkilediğinin açıklanması önem arz etmektedir. Araştırmada yapılan korelasyon analizi sonucunda kabul edilen hipotezlerdeki ilişkilerin, bağımsız ve bağımlı değişkenler kapsamında regresyon analiziyle açıklanmasına yönelik yapılan regresyon analizi bulguları aşağıda yer almaktadır. 
Tablo 3.4. Grup Sargınlı̆̆ının Sosyal Kaytarma Boyutu Üzerindeki Etkisi

\begin{tabular}{|c|c|c|c|c|}
\hline Sosyal Kaytarma & B & Standart Sapma & $\boldsymbol{\beta}$ & Anlamlılık \\
\hline Sabit & 5,216 & 259 & &, 000 \\
\hline Grup Sargınlığı &,- 746 & 079 &,- 558 &, 000 \\
\hline \multicolumn{5}{|c|}{ Sosyal Kaytarma $=5,216+-, 746 \mathrm{X}_{1}$} \\
\hline
\end{tabular}

Tablo 3.4'deki regresyon analizinde belirginlik katsayısı $\left(\mathrm{R}^{2}\right)$ değerine göre, çalışanların sosyal kaytarma davranışlarındaki yaratılan değişkenliğin \%31'i grup sargınlığı tarafından açıklanabilmektedir. Regresyon analizinde bağımlı ve bağımsız değişkenlerin arasındaki ilişkiyi açıklayan regresyon modeli geçerlidir $(F=88,767 ; p<0,001)$. Grup sargınlığının $(\beta=-, 558 ; p<0.01)$ çalışanların sosyal kaytarma davranışlarını olumsuz yönde anlamlı olarak etkilediği görülmektedir. Başka bir deyişle grup sargınlığı düzeyi arttıkça sosyal kaytarma davranışı azalmaktadır. Bu doğrultuda $\mathrm{H}_{1}$ hipotezi kabul edilmiştir.

Tablo 3.5. Grup Sargınlığı Alt Boyutunun (Grubun Sosyal Bütünleşmesi- Grubun Sosyal Çekiciliği) Sosyal Kaytarma Boyutu Üzerindeki Etkisi

\begin{tabular}{|c|c|c|c|c|}
\hline Sosyal Kaytarma & B & Standart Sapma & $\boldsymbol{\beta}$ & Anlamlılı \\
\hline Sabit & 4,633 &, 252 &, 000 \\
\hline $\begin{array}{c}\text { Grubun Sosyal } \\
\text { Bütünleşmesi- } \\
\text { Grubun Sosyal } \\
\text { Çekiciliği }\end{array}$ &,- 558 &, 076 &,- 465 &, 000 \\
\hline $\begin{array}{l}\text { Sosyal Kaytarma= 4,633+-,558X } \\
\left(\mathrm{F}=54,133 \quad \mathrm{R}^{2}=, 216\right)\end{array}$ & $\left(\mathrm{X}_{1}=\right.$ Grubun Sosyal Bütünleşmesi- Grubun Sosyal Çekiciliği $)$ \\
\hline
\end{tabular}

Tablo 3.5'deki regresyon analizi belirginlik katsayısı $\left(\mathrm{R}^{2}\right)$ değerine göre, çalışanların sosyal kaytarma davranışlarındaki yaratılan değişkenliğin \%21'i grup sargınlığı tarafından açıklanabilmektedir. . Regresyon analizinde bağımlı ve bağımsız değişkenlerin arasındaki ilişkiyi açıklayan regresyon modeli geçerlidir $(\mathrm{F}=54,133 ; \mathrm{p}<0,001)$. Grup sargınlığının grubun sosyal bütünleşmesi- grubun sosyal çekiciliği alt boyutu $(\beta=-, 465 ; p<0.01)$ çalışanların sosyal kaytarma davranışlarını olumsuz yönde anlamlı olarak etkilediği görülmektedir. Başka bir deyişle grup sargınlığının alt boyutu olan grubun sosyal bütünleşmesi- grubun sosyal çekiciliği düzeyi arttıkça sosyal kaytarma davranışı azalmaktadır. $\mathrm{Bu}$ doğrultuda $\mathrm{H}_{1 \mathrm{a}}$ ve $\mathrm{H}_{1 \mathrm{c}}$ hipotezi kabul edilmiştir. 
Tablo 3.6. Grup Sargınlığı Alt Boyutunun (Grubun Görev Çekiciliği) Sosyal Kaytarma Boyutu Üzerindeki Etkisi

\begin{tabular}{|c|c|c|c|c|}
\hline Sosyal Kaytarma & $\mathbf{B}$ & Standart Sapma & $\boldsymbol{\beta}$ & Anlamlılık \\
\hline Sabit & 3,882 &, 181 & $\mathbf{0 0 0}$ \\
\hline $\begin{array}{c}\text { Grubun Görev } \\
\text { Çekiciliği }\end{array}$ &,- 340 &, 055 &,- 403 & $\mathbf{0 0 0}$ \\
\hline Sosyal Kaytarma $=3,882+-, 340 \mathrm{X}_{1} \quad\left(\mathrm{X}_{1}\right.$ Grubun Görev Çekiciliği $)$ & $\left(\mathrm{F}=38,078 \quad \mathrm{R}^{2}=, 163\right)$ \\
\hline
\end{tabular}

Tablo 3.6'daki regresyon analizi belirginlik katsayısı $\left(\mathrm{R}^{2}\right)$ değerine göre, çalışanların sosyal kaytarma davranışlarındaki yaratılan değişkenliğin \%16’sı grup sargınlığı tarafından açıklanmaktadır. . Regresyon analizinde bağımlı ve bağımsız değişkenlerin arasındaki ilişkiyi açıklayan regresyon modeli geçerlidir $(\mathrm{F}=38,078 ; \mathrm{p}<0,001)$. Grup sargınlığının diğer bir boyutu olan grubun görev çekiciliği alt boyutu $(\beta=-, 403 ; p<0.01)$ çalışanların sosyal kaytarma davranışlarını olumsuz yönde anlamlı olarak etkilediği görülmektedir.Başka bir deyişle grup sargınlığının alt boyutu olan grubun görev çekiciliği düzeyi arttıkça sosyal kaytarma davranışı azalmaktadır. Bu doğrultuda $\mathrm{H}_{1 \mathrm{~b}}$ hipotezi kabul edilmiştir.

Tablo 3.7. Grup Sargınlığının İş Tatmini Boyutu Üzerindeki Etkisi

\begin{tabular}{|c|c|c|c|c|}
\hline İş Tatmini & $\mathbf{B}$ & Standart Sapma & $\boldsymbol{\beta}$ & Anlamlılık \\
\hline Sabit & 1,984 &, 320 &, 000 \\
\hline Grup Sargınlı̆̆ı &, 527 &, 098 &, 359 &, 000 \\
\hline İş Tatmini=1,984+,527X & $\left(\mathrm{X}_{1}=\right.$ Grup Sargınlığ $) \quad(\mathrm{F}=29,060$ & $\left.\mathrm{R}^{2}=, 129\right)$ \\
\hline
\end{tabular}

Tablo 3.7'deki regresyon analizi belirginlik katsayısı $\left(\mathrm{R}^{2}\right)$ değerine göre, çalışanların iş tatmininde yaratılan değişkenliğin \%12'si grup sargınlığı tarafından açıklanmaktadır. Regresyon analizinde bağımlı ve bağımsız değişkenlerin arasındaki ilişkiyi açıklayan regresyon modeli geçerlidir (F= 29,060; $<<0,001)$. Grup sargınlığının $(\beta=, 359 ; p<0.01)$ çalışanların iş tatminini olumlu yönde anlamlı olarak etkilediği görülmektedir. Başka bir deyişle iş tatmini arttıkça grup sargınlığı düzeyi de artmaktadır. Bu doğrultuda $\mathrm{H}_{2}$ hipotezi kabul edilmiştir.

Tablo 3.8. Grup Sargınlığı Alt Boyutunun (Grubun Sosyal Bütünleşmesi- Grubun Sosyal Çekiciliği) İş Tatmini Boyutu Üzerindeki Etkisi

\begin{tabular}{|c|c|c|c|c|}
\hline İş Tatmini & B & Standart Sapma & $\boldsymbol{\beta}$ & Anlamlılık \\
\hline Sabit & 2,183 &, 293 &, 000 \\
\hline $\begin{array}{c}\text { Grubun Sosyal } \\
\text { Bütünleşmesi- }\end{array}$ &, 460 &, 088 &, 349 &, 000 \\
\hline
\end{tabular}




\begin{tabular}{|l|l|l|l|}
\hline \multicolumn{1}{|c|}{$\begin{array}{c}\text { Grubun Sosyal } \\
\text { Çekiciliği }\end{array}$} & & & \\
\hline $\begin{array}{l}\text { İs Tatmini }=3,183+, 460 \mathrm{X}_{1} \quad\left(\mathrm{X}_{1}=\text { Grubun Sosyal Bütünleşmesi- Grubun Sosyal Çekiciliği }\right) \quad(\mathrm{F}=27,215 \\
\left.\mathrm{R}^{2}=, 122\right)\end{array}$ \\
\hline
\end{tabular}

Tablo 3.8'deki regresyon analizi belirginlik katsayısı $\left(\mathrm{R}^{2}\right)$ değerine göre, çalışanların iş tatminindeki yaratılan değişkenliğin \%12'si grup sargınlığı tarafından açıklanmaktadır. Regresyon analizinde bağımlı ve bağımsız değişkenlerin arasındaki ilişkiyi açıklayan regresyon modeli geçerlidir $(\mathrm{F}=27,215 ; \mathrm{p}<0,001)$. Grup sargınlığının grubun sosyal bütünleşmesi- grubun sosyal çekiciliği alt boyutu $(\beta=, 349 ; \mathrm{p}<0.01)$ çalışanların iş tatminlerini olumlu yönde anlamlı olarak etkilediğgi görülmektedir. Başka bir deyişle iş tatmini arttıkça grup sargınlığının alt boyutu olan grubun sosyal bütünleşmesi- grubun sosyal çekiciliği düzeyi de artmaktadır. Bu doğrultuda $\mathrm{H}_{2 \mathrm{a}}$ ve $\mathrm{H}_{2 \mathrm{c}}$ hipotezi kabul edilmiştir.

Tablo 3.9. Grup Sargınlığı Alt Boyutunun (Grubun Görev Çekiciliği) İş Tatmini Boyutu Üzerindeki Etkisi

\begin{tabular}{|c|c|c|c|c|}
\hline İş Tatmini & B & Standart Sapma & $\beta$ & Anlamlılık \\
\hline Sabit & 3,130 & ,213 & & ,000 \\
\hline $\begin{array}{l}\text { Grubun Görev } \\
\text { Çekiciliği }\end{array}$ &, 175 & ,065 & , 190 & ,007 \\
\hline
\end{tabular}

Tablo 3.9' daki regresyon analizi belirginlik katsayısı $\left(\mathrm{R}^{2}\right)$ değerine göre, çalışanların iş tatminindeki yaratılan değişkenliğin yaklaşık \%4’ü grup sargınlığı tarafından açıklanmaktadır.Regresyon analizinde bağımlı ve bağımsız değişkenlerin arasındaki ilişkiyi açıklayan regresyon modeli geçerlidir $(F=7,319 ; p<0,001)$. Grup sargınlığının diğer bir alt boyutu olan $(\beta=, 190 ; p<0.01)$ grubun görev çekiciliğinin iş tatmini üzerinde olumlu yönde anlamlı bir etkisinin olduğu görülmektedir. Başka bir deyişle iş tatmini arttıkça grup sargınlığının alt boyutu olan grubun görev çekiciliği düzeyi de artmaktadır. $\mathrm{Bu}$ doğrultuda $\mathrm{H} 2 \mathrm{~b}$ hipotezi kabul edilmiştir.

\section{SONUÇ}

Örgüt hedeflerinin üyeler tarafindan benimsenmesi ve hedefler yönünde hareket edilmesi grubun başarısı için gereklidir. Örgüt hedeflerine ulaşmada gruptaki üyelerden birinin daha az çaba sarf etmesi, iş kalitesinde düşüş yaşanmasına neden olabileceği gibi grup içerisinde gerilim yaşanmasına da neden olabilmektedir. Örgüt içinde yer alan bireydeki çabanın azalması, sosyal kaytarma olarak bilinen olumsuz davranışlara yol açmaktadır. Örgüt çalışanlarının grup bağlılığının arttırılması, iş tanımlamalarının ve görevlerinin açık bir biçimde belirtilmesi, grup içindeki performansın bireysel olarak ölçülmesi ve değerlendirilmesi sosyal kaytarma davranışının engellenmesi veya ortadan 
kaldırılması için olumlu yönde etkisi olacaktır. Yapılan araştırmalarda (William ve Karau, 1991; Liden vd., 2004) grup sargınlığının arttırılması, bireysel performansa dayalı ödüllendirme sisteminin gerçekleşmesi, çalışma koşullarında adaletli ve güvenli bir ortamın bulunması ile sosyal kaytarma davranışının gözle görülür biçimde azaldığı görülmektedir.

Lojistik sektörünün insan kaynağına diğer sektörlerden daha fazla önem vermesinin sebebi sektör içerisinde ağırlıklı olarak insan gücünün kullanılıyor olmasıdır. Durumun böyle olması örgütlerdeki insan kaynağı seçiminde amaç ve hedeflere ulaştırmada daha başarılı olan işgörenin seçimiyle gerçekleştirilmektedir. Örgütlerdeki bireylerin ihtiyaçlarının karşılanması ve sektörün koşullarına uyum sağlayabilmeleri için birçok etmenin örgüt veya grup içerinde oluşturulabilmesiyle mümkün olmaktadır. Bu ihtiyaçların karşılanmaması durumunda örgütlerde olumsuz davranışların yaşanması kaçınılmazdır. Benzer nedenler çerçevesinde gruplardaki sargınlığın, kaytarma davranışı ve tatmin düzeylerine etkisi de önem arz eden sorunsallar içinde yerini almaktadır. Bu çerçevede, araştırmada grup sargınlığının sosyal kaytarma ve iş tatmini üzerindeki etkisinin incelenmesi amaçlanmıştır.

Araştırma sonucunda elde edilen bulgularda, grup sargınlığg ve alt boyutlarının sosyal kaytarma davranışı üzerinde anlamlı ve olumsuz etkisinin olduğu belirlenmiş yani grup içindeki sargınlığın artması halinde sosyal kaytarma davranışında azalma yaratacağı gözlemlenmiştir. Grup sargınlığının sosyal kaytarma üzerindeki etkisini inceleyen Karau ve Hart (1998:190), grup içinde sarf ettikleri çabaların diğer üyeler tarafından görüldüğünde daha fazla çaba harcayan bireylerin performanslarının da arttığını buna ek olarak yüksek sargınlığın görüldüğü gruplarda sosyal kaytarma davranışının olmadığını belirtmişlerdir. Dolayısıyla bu çalışmada işgörenlerin grup sargınlık düzeyindeki artış sosyal kaytarma davranışının da azalmasına yardımcı olmuştur. Örgütlerde grup olarak çalışılması halinde yöneticilerin çalışma gruplarının büyüklüğü, örgüt içi iletişim, bireysel değerlendirme ve ödüllendirme faktörlerini dikkate aldıkları takdirde grup sargınlığının olumsuz davranışları engelleyebileceği görülmüştür. Ayrıca grup sargınlığg ve alt boyutlarının iş tatmini üzerinde anlamlı ve olumlu etkisinin olduğu belirlenmiş yani gruptaki sargınlık düzeyindeki artışın işgörenlerin iş tatminin de etkilediği gözlemlenmiştir. İskandar (2019:60) yaptığı araştırmada grup bağlılığının artmasının iş tatminin etkilediğini, bireylerin içinde bulunduğu grup ne kadar yüksek bağlılığa sahip ise bireysel tatminin de o kadar yüksek olduğunu belirtmiştir. Dolayısıyla araştırma sonuçları, üyesi olduğu gruplarda sargınlık düzeylerinde artış yaşanmasının bireylerde işten duyulan tatmini de arttırdığını göstermektedir. Araştırmanın örnekleminde bulunan firma çalışanlarının küçük gruplar halinde çalıştıklarında bağlılık düzeylerinin olumlu yönde etkilendiğini ve bununla beraber olumsuz davranışların engellenebildiği gibi iş tatmin düzeylerinde de etkilendiği görülmüştür. Son olarak araştırmanın diğer lojistik firmalarında veya farklı bir alanda yapılması halinde farklı sonuçlara 
ulaşılabileceği düşünülmektedir. Bu çalışmanın yeni kavramlar içermesi nedeni ve konu ile ilgili literatürde fazla araştırmanın bulunmaması sebebiyle; çalışmada yer alan değişkenlerin grup sargınlığının önem taşıdığı TSK, Polis ve İtfaiye Teşkilatları gibi farklı meslek grubunda çalışılması, grup sargınlığı kavramının spor gruplarına yönelik bir ölçüm modelinin olması ve Türk kültür yapısına uygun olmaması sebebiyle yeni bir ölçüm modeli geliştirilmesi önerilebilir. 


\section{KAYNAKÇA}

Açar, V. (2018). Sağlık Çalışanlarında Sigara ve İnternet Kullanımı ile Sosyal Kaytarma Algısının Değerlendirilmesi. (Yayımlanmamış Yüksek Lisans Tezi). Kırklareli Üniversitesi.

Barlı, Ö. (2007). Davranış Bilimleri, Bizim Büro Basımevi Yayın-Dağıtım, Ankara.

Basım, N. H. ve Şeşen, H. (2009). “Örgütsel Adalet Algısı Örgütsel Vatandaşlık Davranışı İlişkisinde İş Tatmininin Aracılık Rolu”, Osman Gazi Üniversitesi 17. Yönetim ve Organizasyon Kongresi Bildiriler Kitabı, 806-812.

Carron, A. V.; Widmeyer, W. N. ve Brawley, L.R. (1985). "The Development of an İnstrument to Assess Cohesion in Sport Teams: The Group Environment Questionnaire", Journal of Sport Psychology, 7(3), 244-266.

Cota, A. A.; Evans, C. R.; Dion, K. L.; Killik, L. ve Longman, R.S. (1995). "The Structure of Group Cohesion”, Personality and Social Pscyhological Bulletin, 21, 572-580.

Emre, G. (2016). İş Tatmini ve Örgütsel Bağl1lık Etkileşimi: İstanbul İli Lojistik Firmaları Çalışanları Üzerine Bir Uygulama. (Yayımlanmamış Yüksek Lisans Tezi). İstanbul Gelişim Üniversitesi.

Erdoğan, İ. (1996). İşletme Yönetiminde Örgütsel Davranış, Avcılol Yayınları, İstanbul.

Erişen, M. A.; Akman H.D ve Güzel, Ş. (2019). "Örgütsel Bağl1lık ve İş Tatmini Arasındaki İlişki”, International Social Sciences Studies Journal, 5(51), 6909-6915.

George, J. M. (1992). "Extrinsic and Intrinsic Origins of Perceived Social Loafing in Organizations", The Academy Of Management Journal, 35 (1), 191-202.

Hogg, M. A. (1993). "Group Cohesiveness: A Critical Review and Some New Directions", European Review of Social Psychology, 4(1), 85-111.

Ilgın, B. (2010). Örgütsel Vatandaşlık Davranışlarının Oluşumunda ve Sosyal Kaytarma ile İlişkisinde Duygusal Zekanın ve Lider Üye Etkileşiminin Rolü. (Yayımlanmamış Doktora Tezi). Hacettepe Üniversitesi.

Ilgıı, B. (2013). “Toplumsal Bir Hastalık: Sosyal Kaytarma”, Uşak Üniversitesi Sosyal Bilimler Dergisi, 6(3), 238-270.

Kanten, P. (2014). “ İşyeri Nezaketsizliğinin Sosyal Kaytarma Davranışı ve İşten Ayrılma Niyeti Üzerindeki Etkisinde Duygusal Tükenmenin Aracılık Rolü’, Aksaray Üniversitesi İktisadi ve İdari Bilimler Fakültesi Dergisi, 6 (1), 11-26.

Karau, S. J ve Williams, K. D. (1993)." Social Loafing: A Meta-Analytic Review and Theoretical Integration", Journal of Personality and Social Psychology, 65(4), 681706.

Karau, S. J ve Williams, K. D. (1997). "The Effects of Group Cohesiveness on Social Loafing and Social Compensation", Group Dynamics: Theory, Research and 
Practice, 1(2), 156.

Kılıçlarslan, Ö.Ö. (2018). Okul Müdürlerinin Algılarına Göre Öğretmenlerin Sosyal Kaytarma Davranışları. (Yayımlanmamış Yüksek Lisans Tezi). Necmettin Erbakan Üniversitesi.

Kocaekşi, S. (2010). Hentbol Bayan Milli Takımında Zaman Değişimi ve Performansın Grup Sargınlığ 1 , Sportif Kendine Güven, Öz-Yeterlik, Hedef Yönelimi ve Yarışma Kaygısı Üzerine Etkisi. (Yayımlanmamış Doktora Tezi). Hacettepe Üniversitesi.

Kozlowski, S.W. J ve Ilgen, D. R. (2006). "Enhancing the Effectiveness of Work Groups and Teams", Association for Psychological Science, 7 (3), 77-124.

Kök Bayrak, S. (2006). “İş Tatmini ve Örgütsel Bağlılığın İncelenmesine Yönelik Bir Araştırma”. Atatürk Üniversitesi İktisadi ve İdari Bilimler Dergisi, 20(1), 291-317.

Latane, B.; Williams, K. ve Harkins, S. (1979). "Many Hands Make Light The Work: The Causes and Consequences of Social Loafing", Journal of Personality and Social Psychology, 37(6), 822-832.

Liden, R.C; Wayne, S. J; Jaworski, R. A ve Bennett, N. (2004). "Social Loafing: a Field Investigation”, Journal Of Management, 30(2), 285-304.

Mudrack, P. E. (1989). “Defining Group Cohesiveness: A Legacy of Confusion?”, Small Group Bahavior, 20 (1), 37-49.

Öcel, H. ve Aydın, O. (2006). "Grup Sargınlığı Ölçeği: Geçerlik ve Güvenirlik Çalışması”, Türk Psikologlar Derneği, 9 (18), 19-32.

Özpehlivan, M. (2018). "İş Tatmini: Kavramsal Gelişimi, Bireysel ve Örgütsel Etkileri, Yararları ve Sonuçları”, Kırklareli Üniversitesi Sosyal Bilimler Dergisi, 2(2), 4370.

Piezon, S.L. ve Ferree,W. D. (2008). "Perceptions of Social Loafing in Online Learning Groups:A Study of Public University and U.S Naval War College Students", International Review of Research in Open and Distance Learning, 9 (2), 1-17.

Şahal, E. (2005). Akademik Örgütlerde Örgüt Kültürü ve İş Tatmini Arasındaki İlişki: Akdeniz Üniversitesi'nde Doktora Yapan Araştırma Görevlilerinin Örgüt Kültürüne ve İş Tatminine Yönelik Algı ve Kanaatleri. (Yayımlanmamış Yüksek Lisans Tezi). Akdeniz Üniversitesi.

Tümbaşer, Y. (2020). Futbol ve Basketbolcularda Grup Sargınlığı ve Narsistik Kişilik Özeliklerinin İncelenmesi. (Yayımlanmamış Yüksek Lisans Tezi). Çukurova Üniversitesi. 


\section{EXTENDED SUMMARY}

\section{The Effect of Group Cohesiveness on Social Loafing and Job Satisfaction}

\section{INTRODUCTION}

Group cohesiveness has been a concept emphasized by researchers since it plays an important role in ensuring the continuity of groups within the organization (Kowlowski and Ilgen, 2006: 87). The concept of group cohesiveness is expressed as the individuals working as a group to feel like a part of that group and to combine the forces necessary for their survival in the group. Strengthening the bond between the members in the group also affects the increase in the level of group cohesiveness. In addition, it is seen that too much importance given to social relations in order to increase the level of cohesion in the group may cause loss of productivity by creating an effect on the job performance of individuals.

The decrease in social awareness of individuals working in groups, consciously or unconsciously, causes individuals to make less effort than when they are alone, and as a result, the decrease in productivity reveals social loafing behavior (Kanten, 2014: 13). Social loafing behavior, which is the result of working in groups, is an unacceptable behavior in the organization. Because the individual performance of individuals with social loafing behavior cannot be measured clearly and it is seen that less effort is made in group work than in individual work. Social loafing behavior can lead to disappointment in other members of the group, decrease in productivity, inhibition of individual abilities, dissatisfaction and burnout.

Fulfilment of needs of individuals and adapting to intense work tempos depend on many factors such as organizational commitment, communication, productivity, morale and job satisfaction. Accordingly, group cohesiveness, which plays an important role in creating the necessary conditions for increasing productivity and satisfaction in the working environment, will also help prevent negative behaviors if their level in the organization is increased. This information constitutes the starting point of the research. The aim of the research was determined as the examination of the effect of group cohesiveness of individuals working in groups in the logistics sector on social loafing and job satisfaction.

\section{THEORATICAL FRAMEWORK}

The most comprehensive definition of the concept of group cohesiveness, which is also accepted by the theoreticians, is expressed as dynamic processes that are affected by the level of meeting the emotional and instrumental needs of the members in the group and aiming at the interlocking and bonding (Cota et al., 1995: 572). With this definition, the concept of group cohesiveness has been 
examined in a more comprehensive way, and it has also been explained through the concepts of task cohesion and social cohesion. Carron et al. (1992) developed a model to measure and explain the cohesiveness level in groups. In this study, besides examining the concept of group cohesiveness as an individual and a group, they carried out a comprehensive research in which task and environmental connections were added.

According to Carron et al. (1998), when looking at individual and group effects, they stated that the concepts of group integration and group attraction were added to these dimensions, and these two subdimensions were supported in terms of task and social aspects.

With this research, group cohesiveness, group integration-social; the ability to develop and maintain social relations in the group, group integration-task ; task coherence to achieve group goals, individual attraction to group- social; willingness to participate in group-related social activities, individual attractions to group-task; The group has become a four-dimensional structure that expresses the attraction to the purpose in order to achieve the goals related to the group (Carron et al., 1985: 248). This study also supported the explanation of the multidimensional, effective, goal-oriented and interactive elements of the concept of cohesiveness in a meaningful framework. Accordingly, cohesiveness is multidimensional; the wholeness of a group and its dependence on each other may vary according to the groups.

It is observed that working together in groups has positive effects such as increasing the motivation of the individuals to the highest level and an increase in the determination to work. However, in a number of studies, studies have shown that individuals make less effort when they work in groups than when they work individually (Karau and Williams, 1997: 156). It has been observed that the conscious or unconscious decrease in social awareness in groups causes individuals to make less effort alone. It is seen that these productivity losses in organizations are explained by the concept of social loafing. Social loafing behavior is based on the uncertainty of identity that is expected to occur when people work as a group as opposed to working alone (Liden et al., 2004: 285). In this context, all dimensions of the job are effective in the individual's satisfaction with the job. It can be said that the individual who provides a certain degree of satisfaction from his job has compassion and respect for his job.

\section{METHODOLOGY}

The aim of the research is to determine the effect of group cohesiveness on social loafing and job satisfaction. Survey method was used as data collection method in the research. In the survey form, three different scales were used to measure group cohesiveness, social loafing and job satisfaction. Five-interval Likert-type metric expressions were used for the answers of the statements in the scales. 
In the first stage of the analysis; exploratory and confirmatory analyzes were performed. The research was carried out with convenience sampling method in a company operating in the logistics sector in Çanakkale province and its districts. In line with the research permission obtained from the company, blue-collar and white-collar employees were included in the sample. Out of a total of 250 questionnaires submitted to the company, 198 of 222 forms were evaluated. The analysis of the data obtained as a result of the research was carried out using SPSS 24.0 Windows and Lisrel 8.80 package programs. In order to test the relationships between variables in the research; Pearson correlation analysis and regression analysis were used to determine the effect of independent variables on the dependent variable.

\section{RESEARCH FINDINGS}

In the findings obtained as a result of the research, it was determined that group cohesiveness and its sub-dimensions had a significant and negative effect on social loafing behavior, that is, it was observed that if the cohesiveness increases within the group, there will be a decrease in social loafing behavior. In addition, it was determined that the group cohesiveness and its sub-dimensions had a significant and positive effect on job satisfaction, that is, it was observed that the increase in the cohesiveness level in the group also affected the job satisfaction of the employees. Therefore, the results of the research show that an increase in the cohesiveness levels in the groups of which they are members also increases the job satisfaction of the individuals.

\section{CONCLUSION}

The results of the research show that the increase in the cohesiveness levels in the groups of which they are members also increases the job satisfaction of the individuals. It has been observed that when the company employees in the sample of the research work in small groups, their levels of cohesiveness are positively affected, and negative behaviors can be prevented as well as their job satisfaction levels. Finally, it is thought that different results can be achieved if the research is conducted in other logistics companies or in a different field. Due to the fact that this study contains new concepts and there is not much research in the literature on the subject; It can be suggested that a new measurement model should be developed because the variables in the study are working in different occupational groups such as the Police and Fire Department, where group cohesiveness is important, and the concept of group cohesiveness is a measurement model for sports groups. 